\title{
Chemical composition and diuretic potential of the essential oil of Cymbopogon densiflorus (Steud.) Stapf. (Poaceae) in the mouse
}

\author{
A.W. ETOU OSSIBI ${ }^{1 *}$, M.A. ELOUMA NDINGA ${ }^{2}$, C. EPA ${ }^{3}$, \\ B.S. WOSSOLO LINGOMO ${ }^{1}$, M. BONOSE ${ }^{4}$, N. OKEMY ANDISSA ${ }^{1}$, \\ J.M. MOUTSAMBOTE ${ }^{5}$ et A.A. ABENA ${ }^{1}$
}

\author{
${ }^{l}$ Laboratory of Biochemistry and Pharmacologie, Faculty of Health Sciences, University Marien \\ Ngouabi, B.P. 69, Brazzaville, Congo. \\ ${ }^{2}$ Plant and Life Chemistry Unit, Faculty of Sciences Technology, University Marien Ngouabi, B.P. 69, \\ Brazzaville, Congo. \\ ${ }^{3}$ Departement of Natural Sciences, Normal High School, University Marien Ngouabi, B.P. 69, Brazzaville, \\ Congo. \\ ${ }^{4}$ Univ. Paris-Sud, LETIAM, Lip (Sys) ${ }^{2}$, IUT d'Orsay, Moulon Tray, 91400 Orsay, France. \\ ${ }^{5}$ Institute of Research in Exact and Natural Sciences, Brazzaville - Congo. \\ "Corresponding author; E-mail: etouarnaud@yahoo.fr
}

\section{ACKNOWLEDGMENTS}

Our sincere acknowledgments to the authorities of the Faculty of the Sciences and Techniques of the Marien NGOUABI University for the financing of the ionogram.

\begin{abstract}
The present study focused on the diuretic activity of the essential oil (EO) of Cymbopogon densiflorus (Steud.) Stapf and the citral (majoritaire compound). The analysis of the chemical composition of this oil by gas chromatography coupled with mass spectrometry (GC/MS) made it possible to identify several molecules. It emerges from this study that only EO at $150 \mathrm{mg} / \mathrm{kg}$ causes significant diuretic activity (V.U.E $=168.39 \%$ ) such as furosemide; the latter being modest (V.U.E $=143.62 \%$ ) for citral at a dose of $75 \mathrm{mg} / \mathrm{kg}$. In treated mice, removal of sodium was significant and potassium was spared compared to mice treated with distilled water. The diuretic effect of $\mathrm{EO}$ of $C$. densiflorus leaves demonstrated in the present study is a mode of action of this plant that justifies its use in traditional medicine against high blood pressure.
\end{abstract}

(C) 2019 International Formulae Group. All rights reserved.

Keywords: Cymbopogon densiflorus, essential oil, citral, diuretic, diuretic index.

\section{INTRODUCTION}

Diuretics are substances that inhibit the renal reabsorption of sodium and cause urinary excretion of water and sodium. They are used against edema and represent one of the most prescribed classes of drugs in first intention in hypertensive patients. They alone are able to control about $20 \%$ of essential HTA, currently recognized as a real public health problem in the world with regard to 
epidemiological data (Boutin, 2015). However, many of the diuretics currently used in clinical practice are only accessible to a privileged class of populations because of their high costs. Others, however, have been associated with a number of adverse effects, including electrolyte imbalance, metabolic alterations, onset of diabetes and impaired sexual function (Gupta and Neyses, 2005 ; Wile, 2012). Therefore plant extracts (less expensive), are presented as natural alternatives "safe" to conventional diuretics. In the Republic of Congo, several traditional plant-based preparations are used by the local population for their alleged diuretic properties, including a giant citronella species acclimated. The botanical description of this species and the chemical composition of its oil identify it to $C$. densiflorus. Chemical analysis, by GC and GC-MS, of the essential oil from different parts of the plant, extracted at different stages of growth, revealed the very high stability of the citral chemotype $(>80 \%)$. The essential oil of the leaves consisted mainly of $36.24 \%$ of neral and $48.88 \%$ of geranial (Loumouamou et al., 2010). Although much research is devoted to essential oils of the genus Cymbopogon, little information is available about their diuretic activities and their constituents. The purpose of this article was to evaluate the diuretic potential of the essential oil of the fresh leaves of $C$. densiflorus and one of its major constituents.

\section{MATERIALS AND METHODS \\ Plant material}

The leaves of Cymbopogon densiflorus were identified by Professor Jean-Marie Moutsambote at the Center for the Study of Vegetable Resources (C.E.R.VE) of Brazzaville compared to dried herbarium specimens N॰ 15233.

\section{Animal material}

Female albino swiss mice (Mus musculus Linnaeus, 1758) of body weighing between 20 and $30 \mathrm{~g}$ and aged $14 \pm 2$ weeks were used. These animals were provided by the animal facility of the Faculty of Science and Technology of Marien Ngouabi University (Brazzaville, Congo). They were kept under a photoperiodic cycle of $12 \mathrm{~h}$ of light and $12 \mathrm{~h}$ of dark at room temperature of $28 \pm 1{ }^{\circ} \mathrm{C}$ and had free access to standard food and drinking water.

\section{Drugs and chemicals}

Furosemide and sodium chloride were purchased from Sigma-Aldrich, S.L. (USA), deionized water was used in all experimental procedures. Diethyl ether and citral were of analytical grade and purchased from Merck (Darmstadt, Germany).

\section{Extraction procedure}

Fresh leaves of $C$. densiflorus (500 g) were extracted by hydrodistillation, using a Clevenger type apparatus for $5 \mathrm{~h}$. The essential oil was extracted with diethyl ether and dried over anhydrous sodium sulfate. The essential oil solution $(1 \%(\mathrm{v} / \mathrm{v}))$ in diethyl ether was then analyzed by GC-MS.

\section{Analysis condition of the essential oil}

The essential oil was analyzed with a Hewlett Packard (HP) 6890 gas chromatograph coupled with a HP MD5973 quadrupole mass spectrometer. Essential oil was injected using the split mode with a split ratio of 50:1. Helium was the carrier gas at a flow rate of $1.3 \mathrm{~mL}$. $\mathrm{min}^{-1}$. The injector temperature was $250{ }^{\circ} \mathrm{C}$. Compounds were separated on a DB-5 ms capillary column (30 $\mathrm{m} \times 0.25 \mathrm{~mm}$ i.d. $\mathrm{x} 0.25 \mu \mathrm{m}$ film thickness). Oven temperature program started at $40{ }^{\circ} \mathrm{C}$ (held for $1 \mathrm{~min}$ ), heated at $10{ }^{\circ} \mathrm{C} / \mathrm{min}$ up to $130{ }^{\circ} \mathrm{C}$, followed by a $3{ }^{\circ} \mathrm{C} \cdot \mathrm{min}^{-1}$ increase rate up to $250{ }^{\circ} \mathrm{C}$. Electron impact (EI) ion source was set to $150{ }^{\circ} \mathrm{C}$. The electron energy was 70 $\mathrm{eV}$ and mass spectra were collected in the full scan mode (m/z 30-300). The compounds were identified by comparison of their mass spectra with those of standards available in 
commercial mass spectral libraries like the NIST'05 database. The identification of most of the molecules was confirmed by comparison of their experimental Kovat's retention index (IK) with those provided by Adams'book (2001). The retention time of $n$ alkanes to calculate retention index were obtained with a commercial mixture of $\mathrm{C}_{8}-\mathrm{C}_{20}$ in n-hexane. Relative amounts of individual components were calculated on the basis of their GC peak areas.

\section{Evaluation of diuretic activity}

The Basic diuresis was measured by administering to the mice of the water distilled at the rate of $50 \mathrm{ml} / \mathrm{kg}$. Diuretic activity was evaluated according to the method reported by Sanogo and al. (2009). The mice were divided into six groups $(\mathrm{n}=5)$ and were deprived of food (but not water) for $12 \mathrm{~h}$ prior to testing. Each mouse received orally $50 \mathrm{ml} / \mathrm{kg}$ of body weight of isotonic saline $(\mathrm{NaCl}, 1.8 \%)$ to impose a uniform water loading. Each group received primarily a saline solution of $1.8 \%$ (50 $\mathrm{ml} / \mathrm{kg}$ oral administration). Group I, as a negative control, received further distilled water $(50 \mathrm{ml} / \mathrm{kg}$ oral administration); group II additionally received the reference diuretic, furosemide at $20 \mathrm{mg} / \mathrm{kg}$ administered orally. Groups III and IV served as a test group and received the essential oil leaves of $C$. densiflorus orally at doses of 75 and 150 $\mathrm{mg} / \mathrm{kg}$, respectively; groups $\mathrm{V}$ and $\mathrm{VI}$ received citral at doses of 75 and $150 \mathrm{mg} / \mathrm{kg}$, respectively. After these treatments, the 5 mice of the same group were placed in a metabolic cage. Then, for each group, the urine was collected and the following parameters were noted: the delay or time of elimination of the first drop of urine after placing the animals in the metabolic cage, the volume of urine excreted by hour and then after six (6) hours of experimentation. Volumetric Urinary Excretion (EUV) was calculated by the formula:

$$
E U V=\frac{V E}{V A} \times 100
$$

EUV: Volumetric Urinary Excretion (\%);

VE: Volume of Excreted Urine $(\mathrm{mL})$;

VA: Volume of $1.8 \% \mathrm{NaCl}(\mathrm{mL})$.

From the VUE values, the diuretic activity of the various products administered was estimated according to the Kau et al, (1984) scale recorded in Table 1.

\section{Determination of $\mathrm{Na}^{+}, \mathrm{K}^{+}$and $\mathrm{Cl}^{-}$ions}

The urinary $\mathrm{Na}^{+}$and $\mathrm{K}^{+}$concentrations were measured using a Micro Touch Biochemistry Analyzer spectrophotometer. The concentrations of $\mathrm{Cl}^{-}$ions in the urine were determined by flame photometry. The $\mathrm{Na}^{+} / \mathrm{K}^{+}$ratio, diuretic index and ionic quotient were deduced.

Table 1: Estimation of diuretic activity (Kau et al., 1984).

\begin{tabular}{cc}
\hline VUE & Interpretation \\
\hline$<80 \%$ & Anti diuretic \\
$80-110 \%$ & No activity \\
$110-130 \%$ & Low activity \\
$130-150 \%$ & Modest activity \\
$>150 \%$ & Important activity \\
\hline
\end{tabular}

VUE: Volumetric Urinary Excretion. 


\section{RESULTS}

\section{Chemical study}

The essential oil of leaves of $C$. densiflorus was obtained with a yield of 0.22 $\pm 0.02 \%$ (w/w). The compounds identified are listed in Table 2. Of the 16 volatile compounds identified in the essential oil of fresh leaves, citral alone accounts for $85.98 \%$ of the total extract.

\section{Kinetics of urinary excretion and diuretic activity in mice treated with the essential oil of leaves of $C$. densiflorus and Citral Kinetics of urinary excretion}

Table 3 exhibits the volume of urine collected every hour from mice treated with distilled water, $C$. densiflorus essential oil and citral. The essential oil (EO) of $C$. densiflorus $(150 \mathrm{mg} / \mathrm{kg}$ ) causes, like furosemide, short urine elimination times respectively of 18 and $10 \mathrm{~min}$ against $24 \mathrm{~min}$ in the control mice. The essential oil at the dose of $150 \mathrm{mg} / \mathrm{kg}$ causes a maximum elimination of urine from the first hour. In addition, the essential oil of C. densiflorus $(150 \mathrm{mg} / \mathrm{kg})$ and citral $(75$ $\mathrm{mg} / \mathrm{kg}$ ) cause the elimination of urine only during the first 5 hours, such as furosemide (Table 3).

\section{Diuretic activity}

Table 4 shows that the essential oil of C. densiflorus $(150 \mathrm{mg} / \mathrm{kg})$ and Citral $(75$ $\mathrm{mg} / \mathrm{kg}$ ) cause after six hours the elimination of the respective cumulated urinary volumes of; 8.1 and $8.1 \mathrm{~mL}$ versus $4.6 \mathrm{~mL}$ in control mice. Volumetric urinary excretion is greater than $150 \%$ as for furosemide at $20 \mathrm{mg} / \mathrm{kg}$ $(190.11 \%)$ than for the essential oil of C. densiflorus at $150 \mathrm{mg} / \mathrm{kg}(168.39 \%)$. With citral $(75 \mathrm{mg} / \mathrm{kg})$ the value of volumetric urinary excretion is $(143.62 \%)$.

\section{Effects of the essential oil of $C$. densiflorus and citral on the excretion of electrolytes in mice}

Table 5 shows that in the mice treated with the different products, the diuretic indexes are greater than 1 ; except with citral $(150 \mathrm{mg} / \mathrm{kg})$. The $\mathrm{Na}^{+} / \mathrm{K}^{+}$ratios are very high for the $\mathrm{EO}$ at $150 \mathrm{mg} / \mathrm{kg}(9.82)$ and the citral at $150 \mathrm{mg} / \mathrm{kg}(14.81)$ against (5.98) for the control mice. Moreover, it can be seen from Table5 that the ionic quotients in the mice treated with EO (75 and $150 \mathrm{mg} / \mathrm{kg})$ are not between 0.8 and 1 , as for furosemide.

Table 2: Chemical constituents of essential oils of $C$. densiflorus.

\begin{tabular}{cccc}
\hline Pics & RI & Compounds & Peak area $(\%)$ \\
\hline 1 & 986 & 6-methyl-5-hepten-2-one & 2.09 \\
2 & 1095 & linalool & 0.60 \\
3 & 1142 & trans-sabinol & $\operatorname{tr}$ \\
4 & 1153 & citronellal & 0.90 \\
5 & 1156 & $\beta$-pinene oxide & 3.01 \\
6 & 1177 & rosefuran epoxide & 0.21 \\
7 & 1181 & ethyl-3(2-furyl)-propanoate & 3.00 \\
8 & 1237 & neral & 37.00 \\
9 & 1264 & geranial & 48.98 \\
10 & 1359 & z- $\alpha$-damascone & 0.37 \\
11 & 1381 & geranyl acetate & 0.71 \\
12 & 1396 & $\beta$-elemene & 0.89 \\
13 & 1423 & $\beta$-caryophyllene & 0.67 \\
14 & 1515 & $\gamma$-cadinene & 0.56 \\
15 & 1529 & trans-calamenene & $\operatorname{tr}$ \\
16 & 1581 & Caryophyllene oxide & 0.91 \\
Total identified compounds: & & 99.90 \\
Citral & & & 85.98 \\
\hline
\end{tabular}

$\mathrm{RI}=$ retention index on DB-5ms ; $\operatorname{tr}=$ trace. 
Table 3: Kinetics of urinary excretion in mice treated with the essential oil of leaves of $C$. densiflorus and citral.

\section{treatments}

$\mathrm{NaCl} 1,8 \%$ + distilled water $(1 \mathrm{~mL} / 100 \mathrm{~g})$

$\mathrm{NaCl} 1,8 \%+$ Furosemide $(20 \mathrm{mg} / \mathrm{kg})$

$\mathrm{NaCl} 1,8 \%+\mathrm{EO}(75 \mathrm{mg} / \mathrm{kg})$

$\mathrm{NaCl} 1,8 \%+\mathrm{EO}(150 \mathrm{mg} / \mathrm{kg})$

$\mathrm{NaCl} 1,8 \%+$ Citral $(75 \mathrm{mg} / \mathrm{kg})$

$\mathrm{NaCl} 1,8 \%+$ Citral $(150 \mathrm{mg} / \mathrm{kg})$

\section{Time (min)}

Volume of urine eliminated in $\mathrm{mL} / \mathrm{h}$

EO: Essential oil.

\begin{tabular}{|c|c|c|c|c|c|c|}
\hline & 1h & $2 \mathrm{~h}$ & $\mathbf{3 h}$ & $4 h$ & $5 \mathrm{~h}$ & $6 \mathrm{6h}$ \\
\hline 24 & 1,8 & 1 & 0,2 & 0 & 0 & 0 \\
\hline 10 & 6 & 2,8 & 0,5 & 0,5 & 1,2 & 0 \\
\hline 48 & 2 & 1,5 & 0,6 & 0,1 & 0 & 0,6 \\
\hline 18 & 3,8 & 2,2 & 0,2 & 1,8 & 0,1 & 0 \\
\hline 59 & 0,6 & 3,4 & 3 & 1 & 0,1 & 0 \\
\hline 48 & 2,2 & 0 & 0 & 0 & 0 & 0 \\
\hline
\end{tabular}

Table 4: Diuretic activity of the essential oil of leaves of $C$. densiflorus and citral in mice.

\begin{tabular}{cccc}
\hline Treatments & U.V.E $(\mathbf{m L})$ in $\mathbf{6 ~ h}$ & V.U.E $(\%)$ & Conclusion \\
\hline $\mathrm{NaCl} 1.8 \%$ +distilled water $(1 \mathrm{~mL} / 100 \mathrm{~g})$ & 4.6 & 84.09 & No activity \\
$\mathrm{NaCl} 1.8 \%+$ Furosemide $(20 \mathrm{mg} / \mathrm{kg})$ & 10 & 190.11 & Important activity \\
$\mathrm{NaCl} 1.8 \%+\mathrm{EO}(75 \mathrm{mg} / \mathrm{kg})$ & 4.8 & 92.66 & No activity \\
$\mathrm{NaCl} 1.8 \%+\mathrm{EO}(150 \mathrm{mg} / \mathrm{kg})$ & 8.1 & 168.39 & Important activity \\
$\mathrm{NaCl} 1.8 \%+\mathrm{Citral}(75 \mathrm{mg} / \mathrm{kg})$ & 8.1 & 143.62 & Modest activity \\
$\mathrm{NaCl} 1.8 \%+$ Citral $(150 \mathrm{mg} / \mathrm{kg})$ & 2.2 & 38.13 & Anti diuretic \\
\hline
\end{tabular}

EO: Essential oil, U.V.E: Urinary volume excreted, VU.E: Volumetric urinary excretion.

Table 5: Data on diuretic index and urinary excretion of electrolytes in mice treated with $C$. densiflorus essential oil and citral.

\begin{tabular}{|c|c|c|c|}
\hline Treatments & Diuretic index & Ratio $\mathrm{Na}^{+} / \mathrm{K}^{+}$ & Ionic quotient \\
\hline $\mathrm{NaCl} 1,8 \%$ + distilled water $(1 \mathrm{ml} / 100 \mathrm{~g})$ & 1 & 5,98 & 1,12 \\
\hline $\mathrm{NaCl} 1,8 \%+$ Furosemide $(20 \mathrm{mg} / \mathrm{kg})$ & 2,17 & 6,16 & 1,03 \\
\hline $\mathrm{NaCl} 1,8 \%+\mathrm{EO}(75 \mathrm{mg} / \mathrm{kg})$ & 1,04 & 6,53 & 1,15 \\
\hline $\mathrm{NaCl} 1,8 \%+\mathrm{EO}(150 \mathrm{mg} / \mathrm{kg})$ & 1,76 & 9,82 & 1,13 \\
\hline $\mathrm{NaCl} 1,8 \%+$ Citral $(75 \mathrm{mg} / \mathrm{kg})$ & 1,76 & 14,81 & 0,95 \\
\hline $\mathrm{NaCl} 1,8 \%+$ Citral $(150 \mathrm{mg} / \mathrm{kg})$ & 0,48 & 2,98 & 0,94 \\
\hline
\end{tabular}




\section{DISCUSSION}

The average yield of essential oils of this variety is comparable to those reported by other authors (Loumouamou et al., 2010; Nguimale, 2016). The results of the chemical analysis of the essential oil of the leaves confirm those published by Loumouamou et al. (2010), which revealed the very high stability of the citral chemotype for this specimen. The EO of C. densiflorus (150 $\mathrm{mg} / \mathrm{kg}$ ) causes, like furosemide, the elimination of the first drop of urine earlier compared to the control mice. Both products therefore have short diuretic action times. This result suggests that leaf EO of $C$. densiflorus has a fleeting and rapid diuretic effect in mice such as furosemide (Amonkan et al., 2013). Similarly, like furosemide, the essential oil (EO) at a dose of $150 \mathrm{mg} / \mathrm{kg}$ causes maximum elimination of urine from the 1 st hour. In addition, EO at $150 \mathrm{mg} / \mathrm{kg}$ and citral at 75 $\mathrm{mg} / \mathrm{kg}$ cause the elimination of urine only during the first 5 hours, such as furosemide. Previous work has shown that furosemide at doses between 10 and $20 \mathrm{mg} / \mathrm{kg}$ exerts its diuretic effect during the first five hours (Sanogo et al., 2009, Parasuraman and Raveendran, 2012). Also, in the mice treated with $\mathrm{EO}$ at $150 \mathrm{mg} / \mathrm{kg}$, the volumetric urinary excretion is greater than $150 \%$ as in the mice that received the furosemide $(20 \mathrm{mg} / \mathrm{kg})$. These results suggest that this oil $(150 \mathrm{mg} / \mathrm{kg})$ has, like furosemide $(20 \mathrm{mg} / \mathrm{kg})$, a significant diuretic activity, according to the Kau et al. (1984) scale. Several plant extracts or medicinal recipes have also shown important diuretic effects. This is the case of Trema orientalis and Lippia multiflora (Akinda, 2013), the infused Portulaca oleracea (Diallo et al., 2001 and 2010), the Nitrokoudang recipe (Sanogo et al., 2009), of Ziziphus mauritiana (Ba, 2005) and Spondias mombin (Guindo, 2005). Regarding the $\mathrm{Na}^{+} / \mathrm{K}^{+}$ratio, the results show that they are very high for EO at $150 \mathrm{mg} / \mathrm{kg} 9.82$ and citral at $150 \mathrm{mg} / \mathrm{kg}$ 14.81 against 5.98 for mice witnesses. These results suggest that this oil would cause the elimination of sodium ions more than potassium ions. Like other test products used and furosemide, this oil could be considered a good diuretic, sparing potassium ions. Indeed, it is reported that a good diuretic is one that causes a strong elimination of sodium and spares potassium (Dembélé, 2009). Diuretic indices greater than 1 in the mice that received the test products at different doses (except citral $150 \mathrm{mg} / \mathrm{kg}$ ) or furosemide $20 \mathrm{mg} / \mathrm{kg}$ indicate that these products would cause diuresis more important than distilled water. In sum, these results suggest that, of all the test products used, it is probably the EO of $C$. densiflorus that acts according to the same mechanism as furosemide. Indeed, furosemide causes increased sodium excretion with water by inhibiting the co-transporter $\mathrm{Na}^{+} / \mathrm{K}^{+} / 2 \mathrm{Cl}^{-}$ responsible for the reabsorption of sodium and water at the level of the ascending limb of the Henle (Amonkan, 2013). This increased elimination of sodium and water would be beneficial in the treatment of high blood pressure and edema. In the mice given the EO, at the two doses, the ionic quotient is not between 0.8 and 1 as in the control mice. It is reported that substances that do not cause the ionic quotient between 0.8 and 1 inhibit carbonic anhydrase (Netsanet et al., 2017). However, the inhibition of carbonic anhydrase leads to the inhibition of the concomitant reabsorption of bicarbonates, sodium and chlorine, at the level of the proximal tubule. By this mechanism, these substances also have a diuretic effect, although low (Thomas, 2000). Thus, it is possible to suggest that the $\mathrm{EO}$ of $C$. densiflorus could, unlike furosemide and the other extracts of $C$. densiflorus studied, exert its diuretic effect by a second mechanism: the inhibition of carbonic anhydrase. This second mechanism could explain the important diuretic activity observed with this oil in the present study compared to the other extracts studied of this plant. 


\section{Conclusion}

These results suggest that both substances (EO and Citral) tested, it is probably the $\mathrm{OE}$ of the leaves of $C$. densiflorus which acts like the furosemide, reference molecule reputed powerful diuretic. A study evaluating the antihypertensive effects of these extracts is worthwhile.

\section{COMPETING INTERESTS}

The authors declare that they have no competing interests.

\section{AUTHORS' CONTRIBUTIONS}

MB and MAEN carried out the extraction and analysis of the essential oil. JMM realized the botanical identification of the studied species. AAA, CE, AWEO, NOA and BSWL performed the biological activity, data processing, data analysis and writing the article.

\section{REFERENCES}

Akinda A. 2013. Evaluation du pouvoir diurétique des extraits aqueux de Trema orientalis Schum (Ulmaceae) et de Lippia multiflora Mold. (Verbenaceae), Mémoire de Master, Université Marien Ngouabi, Brazzaville, p. 31.

Amonkan KA, Konan AB, Bleyere MN, Ahui BML, Kouakou LK, Bouafou GMK, Kati-Coulibaly S. 2013. Comparative effects of Ficus exasperata aqueous leaf extract and furosemide on urinary excretion in DOCA-Salt hypertensive rat. Journal of Medical Sciences, 13(5) : 385-390.

DOI : 10.3923/jms.2013.385.390.

Ba SHG. 2005. Etude de la phytochimie et des activités biologiques de Zizyphus mauritiana Lam (Rhamnaceae) utilisée dans le traitement traditionnel du diabète et de l'hypertension artérielle au Mauritanie. Thèse de Doctorat en Pharmacie, FMPOS, Bamako, p. 120.

Boutin F. 2015. Etude épidémiologique lors d'une campagne de dépistage, du diabète, de l'hypertension artérielle et de l'obésité androïde à Pointe Noire, République du Congo en 2014, six ans après celle de 2008. Thèse de Doctorat en médecine, Université Lille 2, Lille, p. 37-38.

Bruneton J. 1993. Pharmacognosie, Phytochimie, Plantes médicinales, (2 ème édition). TEC : Paris, p. 915.

Dembélé O. 2009. Etude de la phytochimie de l'activité diurétique d'Hibiscus sabdariffa et de la recette Nitrokoudang dans le traitement traditionnel de l'hypertension artérielle au Mali. Thèse de Doctorat en Pharmacie, FMPOS, Bamako, p. 118-127.

Diallo D, Guissou PI, Mahamane H, Coumbo T, Ossy MJK. 2010. Recherche sur la médecine traditionnelle africaine: hypertension. African Traditional Medecine Day, 14 : 60 -62.

Guindo I. 2005. Etude du traitement traditionnel de l'hypertension artérielle au Mali. Thèse de Doctorat en pharmacie, FMPOS, Bamako, p. 126.

Kau ST, Kaddie JR, Andrews D. 1984. A method for screening diuretic agents in the rat. Journal of Pharmacological Méthods, 11: 67-75. DOI: 10.1016/01605402(84)90054-8.

Loumouamou AN, Biassala E, Silou Th, Ntondele-Nsansi P, Diamouangana J, Nzikou JM, Chalchat JC \& Figuérédo G. 2010. Characterisation of a Giant Lemon Acclimatised in the Congo-Brazzaville. Advence Journal of Food Science and technology, 2(6): 312-371.

Netsanet F, Hirut B, Asfaw M, Sileshi D, Biruktawit G, et Bekesho G. 2017. Diuretic activity of the aqueous crude extract and hot tea infusion of Moringa stenopetala (Baker f.) Cufod. leaves in rats. Journal of Experimental Pharmacology, 9: 73-76. DOI: 10.2147/JEP.S133778. 
Nguimale KBT. 2016. Evaluation de l'activité insecticide de l'huile essentielle de Citronelle (Variété géante Lemon Grass) contre les larves de Desmestes sp. Mémoire de Master, Université Marien Ngouabi, Brazzaville, p. 16-36.

Ourida C. 2012. Composition chimique et activité antibactérienne des huiles essentielles des feuilles de Glycyrrhiza glabra. These de doctorat Es-sciences Université d'Oran, République d'Algérie, p. 64.

Parasuraman S. et Raveendran R. 2012. Diuretic effects of Cleistanthin A et Cleistanthin B from the leaves of Cleistanthusc collinus in wistar rats. $J$. Young Pharm., 4(2): 73-77. DOI: 10.4103/0975-1483.96616.

Sanogo R, Karadji AH, Dembélé O, Diallo D. 2009. Activité diurétique et salidiurétique d'une recette utilisée en médicine traditionnelle pour l'hypertension artérielle: Mali medical, 24(4) : 1-6.

Thomas MC. 2000. Diuretics, ACE inhibitors and NSAIDs-the triple whammy. Med. $J$. Aust. 172(4): 184-189.

Gupta S, Neyses L. 2005. Diuretic usage in heart failure: a continuing conundrum in 2005. Eur. Heart J., 26: 644-649.

Wile D. 2012. Diuretics. A review. Ann. Clin. Biochem., 49 (5): $\quad 419-431 . \quad$ DOI: 10.1258/acb.2011.011281

Adams RP. (2001) Identification of essential oil components by gaz chromatography: quadrupole mass spectroscopy. Allured Pub. Corp: Carol Stream.

WWW.pifo.uvsq.fr consulté le 11/10/2017 à 13:16. 